\title{
PEO- $\left[\mathrm{M}(\mathrm{CN})_{5} \mathrm{NO}\right]^{x-}(\mathrm{M}=\mathrm{Fe}, \mathrm{Mn}$, or $\mathrm{Cr})$ Interaction as a Driving Force in the Partitioning of the Pentacyanonitrosylmetallate Anion in ATPS: Strong Effect of the Central Atom
}

\author{
Luis Henrique M. da Silva, ${ }^{*}, \dagger$ Maria C. Hespanhol da Silva ${ }^{\dagger}{ }^{\dagger}$ Kelly R. Francisco, ${ }^{\dagger}$ \\ Marcus V. C. Cardoso, ${ }^{\dagger}$ Luis A. Minim, ${ }^{\ddagger}$ and Jane S. R. Coimbra \\ Departamento de Química and Departamento de Tecnologia de Alimentos, Centro de Ciências Exatas e \\ Tecnológicas, Universidade Federal de Viçosa, Av. P. H. Rolfs, Viçosa, MG, 36560-000, Brazil
}

Received: December 10, 2007; Revised Manuscript Received: June 11, 2008

\begin{abstract}
The partitioning behavior of pentacyanonitrosilmetallate complexes $-\left[\mathrm{Fe}(\mathrm{CN})_{5} \mathrm{NO}\right]^{2-},\left[\mathrm{Mn}(\mathrm{CN})_{5} \mathrm{NO}\right]^{3-}$, and $\left[\mathrm{Cr}(\mathrm{CN})_{5} \mathrm{NO}\right]^{3-}$-has been studied in aqueous two-phase systems (ATPS) formed by adding poly(ethylene oxide) (PEO; $\left.4000 \mathrm{~g} \mathrm{~mol}^{-1}\right)$ to an aqueous salt solution $\left(\mathrm{Li}_{2} \mathrm{SO}_{4}, \mathrm{Na}_{2} \mathrm{SO}_{4}, \mathrm{CuSO}_{4}\right.$, or $\left.\mathrm{ZnSO}_{4}\right)$. The complexes partition coefficients $\left(K_{\text {complex }}\right)$ in each of these ATPS have been determined as a function of increasing tieline length (TLL) and temperature. Unlike the partition behavior of most ions, $\left[\mathrm{Fe}(\mathrm{CN})_{5} \mathrm{NO}\right]^{2-}$ and $\left[\mathrm{Mn}(\mathrm{CN})_{5^{-}}\right.$ $\mathrm{NO}]^{3-}$ anions are concentrated in the polymer-rich phase with $K$ values depending on the nature of the central atom as follows: $K_{\left[\mathrm{Fe}(\mathrm{CN})_{5} \mathrm{NO}_{2-}\right]^{-}} \gg K_{\left[\mathrm{Mn}(\mathrm{CN})_{5} \mathrm{NO}_{3}\right]^{-}}>K_{\left[\mathrm{Cr}(\mathrm{CN})_{5} \mathrm{NO}\right]^{3-}}$. The effect of ATPS salts in the complex partitioning behavior has also been verified following the order $\mathrm{Li}_{2} \mathrm{SO}_{4}>\mathrm{Na}_{2} \mathrm{SO}_{4}>\mathrm{ZnSO}_{4}$. Thermodynamic analysis revealed that the presence of anions in the polymer-rich phase is caused by an $\mathrm{EO}-\left[\mathrm{M}(\mathrm{CN})_{5} \mathrm{NO}\right]^{x-}$ $(\mathrm{M}=\mathrm{Fe}, \mathrm{Mn}$, or $\mathrm{Cr}$ ) enthalpic interaction. However, when this enthalpic interaction is weak, as in the case of the $\left[\mathrm{Cr}(\mathrm{CN})_{5} \mathrm{NO}\right]^{3-}$ anion $\left(K_{\left[\mathrm{Cr}(\mathrm{CN})_{5} \mathrm{NO}\right]^{3-}}<1\right)$, entropic driving forces dominate the transfer process, then causing the anions to concentrate in the salt-rich phase.
\end{abstract}

\section{Introduction}

Mixtures containing polymers and ions have emerged as a new generation of materials with tremendous potential in fields like nanotechnology and handling of solid electrolytes. ${ }^{1,2}$ More specifically, it is recognized that blends formed with salts of pentacyanonitrosilmetallate $\left(\mathrm{Na}_{x}\left[\mathrm{M}(\mathrm{CN})_{5} \mathrm{NO}\right]\right)$ and poly(ethylene oxide) may produce supramolecular devices suitable for switching purposes and different kinds of signal processing in digital, analogical, or integrated circuits. ${ }^{3-5}$ Almost all strategic properties featured by this kind of material are mainly due to polymer-ion interactions. ${ }^{6}$ The potential technological applications for water-soluble macromolecules in combination with ions make the study of this kind of molecular interaction a very important field. Binding of electrolytes to macromolecules has been investigated by a variety of techniques, including molecular dynamics, ${ }^{7}$ Raman spectroscopy, ${ }^{8}$ and ultrafiltration. ${ }^{9}$ Another useful method to determine polymer-ion interaction, which does not make use of membranes, is to study the partitioning behavior of a target ion between two phases, one of them consisting of an aqueous solution of polymer. ${ }^{10}$

Aqueous mixtures of two dissimilar polymers or a polymer and an inorganic salt are known to separate into two distinct layers depending on the thermodynamic conditions. ${ }^{11}$ This kind of biphasic system is called aqueous two-phase systems, ATPS, with each layer comprising $80 \%$ (or more) of water. ATPS composed of poly(ethylene oxide) (PEO) as the polymer and inorganic salts also have great potential to extract ions from aqueous solutions. ${ }^{12}$ However, in order to realize the full potential of aqueous biphasic separations, research is needed

* To whom correspondence should be addressed. Phone: +553138993052 . Fax: +553138993065. E-mail: luhen@ufv.br.

† Departamento de Química.

$\$$ Departamento de Tecnologia de Alimentos. in order to acquire a better understanding of the parameters that govern solute distribution.

In the research of ion partitioning in ATPS, most published work focuses on the experimental determination of partition coefficients, showing that their values, for almost all cations and anions, are lower than $1 .{ }^{13}$ Surprisingly, there are only two anions, pertechnetate $\left(\mathrm{TcO}_{4}{ }^{-}\right)$and pentacyanonitrosylferrate $\left(\left[\mathrm{Fe}(\mathrm{CN})_{5} \mathrm{NO}\right]^{2-}\right)$, that have strong affinity with the polymerrich phase. Rogers et al. explained pertechnetate's preference for the PEO-rich phase based on its large polarizable nature and the low value of its estimated Gibbs free energy of hydration $\left(\Delta_{\text {hyd }} G^{\mathrm{o}}\right) .{ }^{14}$ This model considers water-anion interactions as the driving force for the ion partitioning behavior. On the other hand, the transfer process of the pentacyanonitrosylferrate anion has been attributed to specific PEO- $\left(\left[\mathrm{Fe}(\mathrm{CN})_{5} \mathrm{NO}\right]^{2-}\right.$ enthalpic interactions. ${ }^{15}$ However, the driving forces which are responsible for the partition of different ions in ATPS are still not known.

In this paper, the influence of the metallic center on the $\left[\mathrm{M}(\mathrm{CN})_{5} \mathrm{NO}\right]^{x-}$ partition behavior has been evaluated. As proposed by da Silva et al., ${ }^{15}$ the NO electronic density contributes to the $\mathrm{PEO}-\left(\left[\mathrm{Fe}(\mathrm{CN})_{5} \mathrm{NO}\right]^{2-}\right.$ interaction, and this molecular property could be modulated by the nature of the central atom. In order to better describe the nature of this kind of molecular interaction, changes in the transfer thermodynamic properties $\left(\Delta_{\mathrm{tr}} G^{\mathrm{o}}, \Delta_{\mathrm{tr}} H^{\mathrm{o}}, \Delta_{\mathrm{tr}} S^{\mathrm{o}}\right)$ have been obtained.

\section{Experimental Section}

Reagents. Poly(ethylene oxide), PEO, with an average molar mass of $4000 \mathrm{~g} \mathrm{~mol}^{-1}$ (according to the manufacturer) was purchased from ISOFAR (Brazil). $\mathrm{ZnSO}_{4}, \mathrm{CuSO}_{4}, \mathrm{Li}_{2} \mathrm{SO}_{4}$, $\mathrm{Na}_{2} \mathrm{SO}_{4}$, and $\mathrm{Na}_{2}\left[\mathrm{Fe}(\mathrm{CN})_{5} \mathrm{NO}\right]$ were obtained from VETEC (Brazil). $\mathrm{K}_{3}\left[\mathrm{Cr}(\mathrm{CN})_{5} \mathrm{NO}\right]$ and $\mathrm{K}_{3}\left[\mathrm{Mn}(\mathrm{CN})_{5} \mathrm{NO}\right]$ were synthesized and purified as described in the literature. ${ }^{16,17}$ All chemicals 
were of analytical grade, and deionized water $(R \geq 18 \mathrm{M} \Omega$ $\mathrm{cm}^{-1}$ ) was used throughout all experiments.

Determination of Phase Diagrams. Ternary phase diagrams of the $\mathrm{PEO} / \mathrm{Y}_{x} \mathrm{SO}_{4} / \mathrm{H}_{2} \mathrm{O}\left(\mathrm{Y}=\mathrm{Li}^{+}, \mathrm{Na}^{+}, \mathrm{Cu}^{2+}\right.$, or $\left.\mathrm{Zn}^{2+}\right)$ system were determined at $(278.15,298.15,308.15$, or $318.15 \mathrm{~K})$. The prepared samples were allowed to phase separate for $48 \mathrm{~h}$ in a thermostatic bath (Schott Gerät GMBH, model CT54HT, Germany), but a period of time of approximately $0.5 \mathrm{~h}$ was sufficient to form two macroscopic, well-defined phases. The polymer and sulfate concentrations in each of the separate phases were determined with two independent methods. The salt concentrations $\left(\mathrm{M}_{x} \mathrm{SO}_{4}\right)$ were determined using atomic absorption spectrophotometry (Carl Zeiss JENA model AAS-3, Germany). The standard deviation in the salt mass percent by this method was $\pm 0.06 \%$. The concentration of the poly(ethylene oxide) in the phases was determined, after suitable dilution, by measuring the total refractive index of the solution and then subtracting the refractive index contribution due to the sulfate salt at this concentration. To do this, standard curves were established for aqueous solutions of PEO, $\mathrm{Li}_{2} \mathrm{SO}_{4}, \mathrm{Na}_{2} \mathrm{SO}_{4}$, $\mathrm{ZnSO}_{4}$, and $\mathrm{CuSO}_{4}$. The validity of the refractive index additivity was also confirmed using test samples. A 09-2001 model Analytic Jena AG Abbe refractometer (Germany) was used for the refractive index measurements.

Preparation of the Aqueous Two-Phase Systems. Aqueous two-phase systems were prepared in $60 \mathrm{~mL}$ graduated centrifuge tubes by weighing stock aqueous solutions of PEO and salt according to the binodal diagrams described above and other diagrams reported by Coimbra et al. ${ }^{18,19}$ (55\% (w/w) PEO, $\mathrm{Li}_{2} \mathrm{SO}_{4} 25 \%$ (w/w); $\mathrm{Na}_{2} \mathrm{SO}_{4} 20 \%$ (w/w); $\mathrm{ZnSO}_{4} 30 \%$ (w/w); $\mathrm{CuSO}_{4} 23 \%$ (w/w)). The resultant mixtures were allowed to stir for $60 \mathrm{~s}$ and then brought to equilibration in a thermostatic bath for $48 \mathrm{~h}$ at the desired temperature $(278.15,298.15,308.15$, or $318.15 \mathrm{~K}$ ). The phases were separated, and subsequently, $3.0 \mathrm{~g}$ of each phase was mixed to reconstitute several two-phase systems in which complexes partition was assayed.

Determination of the Complexes Partition Coefficient. A $100 \mu \mathrm{L}$ amount of $0.100 \%(\mathrm{w} / \mathrm{w})$ complex stock solution was added on $6.0 \mathrm{~g}$ of ATPS. The systems were mixed for $60 \mathrm{~s}$ and then brought to equilibration in a thermostatic bath for $48 \mathrm{~h}$ at the desired temperature $(278.15,298.15,308.15$, or $318.15 \mathrm{~K})$ since previous tests indicated that this period of time was sufficient to ensure thermodynamic equilibrium. After this time, the two phases became reddish with a well-defined interface. Samples were withdrawn from the separated phases, and after appropriate dilution, the complex content was determined in each phase by measuring the absorbance at 260, 302, and $221 \mathrm{~nm}$ for $\mathrm{Na}_{2}\left[\mathrm{Fe}(\mathrm{CN})_{5} \mathrm{NO}\right], \mathrm{K}_{3}\left[\mathrm{Cr}(\mathrm{CN})_{5} \mathrm{NO}\right]$, and $\mathrm{K}_{3}\left[\mathrm{Mn}(\mathrm{CN})_{5} \mathrm{NO}\right]$, respectively. Spectrophotometric measurements were performed with a Cary 50 Probe spectrophotometer from Varian (Mulgrave, Victoria, Australia). Correspondingly diluted phases from aqueous two-phase system, not containing the complexes, were used as blanks. The partition coefficient was thus defined as

$$
K=\frac{[\text { complex }]_{\text {top }}}{[\text { complex }]_{\text {bottom }}}
$$

where $[\text { complex }]_{\text {top }}$ and $[\text { complex }]_{\text {bottom }}$ are the equilibrium concentrations of the partitioned complexes in the PEO- (top) and salt- (bottom) rich phases, respectively. Samples were analyzed in triplicate, and the relative standard deviation for the $K$ values was lower than $2.0 \%$.

For ATPS formed with $\mathrm{CuSO}_{4}$, all complex precipitated, which impaired examination of the partition behavior. For this reason, no further investigation was carried out with the $\mathrm{PEO} /$ $\mathrm{CuSO}_{4} / \mathrm{H}_{2} \mathrm{O}$ system.

Determination of the Calorimetric Transfer Enthalpy. The transfer enthalpy measurements were made by isothermal titration calorimetry (ITC) methodology. ITC experiments were performed using a CSC-4200 (Calorimeter Science Corp.) microcalorimeter, controlled by ItcRun software. The reaction cells (sample and reference) volume of the instrument is 1.8 $\mathrm{mL}$, and the titrant was added in $10 \mu \mathrm{L}$ (Hamilton microliter syringe) increments with time between injections equal to 60 min. The calorimeter was previously chemical $(\mathrm{HCl} /$ Tris titration) and electrical calibrated. During the measurement, $10 \mathrm{mg}$ of the complex was dissolved in $1.8 \mathrm{~mL}$ of the bottom phase and placed in the ampule stirring at $300 \mathrm{rpm}$. The experiments consisted of consecutive injections of top phase into the calorimeter cell that initially contained (a)10 $\mathrm{mg}$ of $\left[\mathrm{M}(\mathrm{CN})_{5} \mathrm{NO}\right]^{x-}$ dissolved into $1.8 \mathrm{~mL}$ of bottom phase or (b) $1.8 \mathrm{~mL}$ of pure (without complex) bottom phase. As the top phase is added, the cell volume is kept constant by an overflow of solutions, which is taken into account in the calculations of actual amount of complex transferred. Before calculation of the transfer enthalpy from titration, the net heat of titration should be obtained by the following equation

$$
q_{\text {inet }}=q_{i \mathrm{a}}-q_{i \mathrm{~b}}
$$

in which $q_{i \mathrm{a}}$ and $q_{i \mathrm{~b}}$ are the heats of the $i$ th injection associated with experiments of groups a and b, respectively. $q_{\text {inet }}$ is the energy associated only with the complex transfer from the bottom phase to the top phase, while in the $q_{i a}$ heat exist the contribution of the energy due the interface formation expressed by $q_{i b}$. $\Delta_{\mathrm{tr}} H$ was calculated by $\partial Q_{t i} / \partial n_{t i}$ of the curve $Q_{t i} n_{t i}$, where $Q_{t i}=\sum_{1}^{i} q_{\text {inet }}$ and $n_{t i}=10 \operatorname{in}_{0} K / 1.8+10 i K$ in which $n_{0}$ is the initial amount of anion $\left[\mathrm{M}(\mathrm{CN})_{5} \mathrm{NO}\right]^{x-}$ dissolved on the bottom phase and $K$ is the complex partitioning coefficient. For calculation of each $\Delta_{\text {tr }} H$ value, at least 20 injections $(i=1$ until 20) were added to the calorimeter cell. All calculated $\Delta_{\mathrm{tr}} H$ relative standard deviations were lower than $1.0 \%$.

\section{Results and Discussion}

Phase Diagrams. Formation of aqueous two-phase systems occurs through mutual exclusion of the salt and polymer, whereby both components present high affinities with the water molecules. With increasing polymer or salt concentration, the extent of exclusion will increase, thus causing the lower phase to concentrate salt and the top phase to be enriched with polymer. At constant pressure and temperature, the chemical potential of all components and consequently their molecular interactions become functions of their concentrations in each ATPS phase. ${ }^{20}$

In order to obtain thermodynamic data and establish a relationship between the tie-line length (TLL) and the complexes partitioning behavior, four phase diagrams of aqueous two-phase systems containing $\mathrm{PEO}$ as the polymer component and sulfate salts $\left(\mathrm{Na}_{2} \mathrm{SO}_{4}, \mathrm{Li}_{2} \mathrm{SO}_{4}, \mathrm{CuSO}_{4}, \mathrm{ZnSO}_{4}\right)$ as the electrolyte component have been constructed and are shown in Figure 1.

The binodal line separates the outer two-phase region from the monophasic region, which lies between the binodal line and the origin of the diagram. The intersecting points of the tie-line with the binodal line establish the phase's compositions. It is clear from the phase diagrams that the effectiveness of the four salts to induce phase separation on the $\mathrm{PEO}$ aqueous solutions is different and follows the order $\mathrm{Na}_{2} \mathrm{SO}_{4}>\mathrm{CuSO}_{4} \cong \mathrm{ZnSO}_{4}$ $>\mathrm{Li}_{2} \mathrm{SO}_{4}$. Calorimetric measurements ${ }^{21}$ have revealed that in a mixture containing sulfate salt and PEO, interactions are 


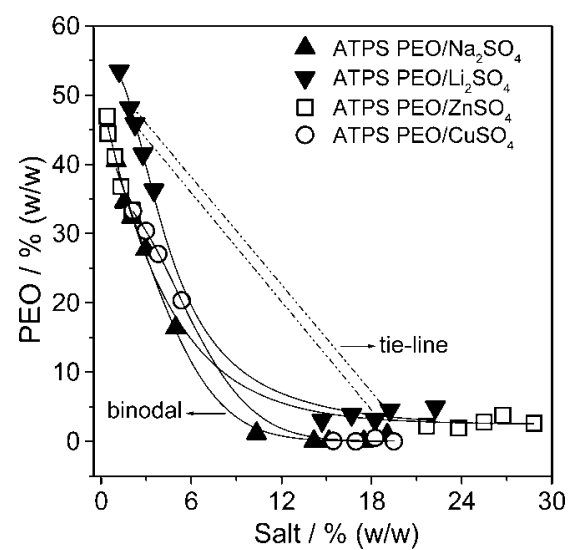

Figure 1. Phase diagram for $\mathrm{PEO} / \mathrm{Y}_{x} \mathrm{SO}_{4}$ at $298.15 \mathrm{~K}\left(\mathrm{Y}=\mathrm{Na}^{+}, \mathrm{Li}^{+}\right.$, $\mathrm{Zn}^{2+}$, or $\mathrm{Cu}^{2+}$ ).

promoted between the ions and the macromolecule and formation of the ion-PEO pair occurs due to some water molecules being released from the ion and EO solvation layers in a process driven by entropy increase. According to this model, the phase splitting occurs as a result of the fact that by adding more salt the systems are subjected to reach some salt concentration levels where the polymeric chains become saturated with the ions and no more entropy gain can be attained. After this saturation point addition of more salt would lead to a higher concentration in the bulk than around the polymer and the phase separation process become more favorable. A natural consequence of this model is that upon lowering of the ion-PEO binding constant the electrolyte becomes more efficient to induce phase separation. In addition, after phase separation the polymer-rich phase will have pseudopolication formed due to the interactions established between the macromolecule and the cations. This positive charge density around the macromolecule favors the interaction with negatively charged species.

By increasing the tie-line length parameter, there is an increase in the difference between both phases in terms of intensive thermodynamic properties. The TLL is determined by the difference in concentration of specific components in the systems formed and calculated according to eq 3

$$
\mathrm{TLL}=\left[\left(C_{\mathrm{P}}^{\mathrm{T}}-C_{\mathrm{P}}^{\mathrm{B}}\right)^{2}+\left(C_{\mathrm{S}}^{\mathrm{T}}-C_{\mathrm{S}}^{\mathrm{B}}\right)^{2}\right]^{1 / 2}
$$

where $C_{\mathrm{P}}$ and $C_{\mathrm{S}}$ refer to polymer and salt concentrations in $\%$ (w/w) and $\mathrm{T}$ and $\mathrm{B}$ denote the top and bottom phases, respectively. For each ATPS, the partitioning coefficient of the complexes was determined in five different tie-line lengths. Generally, based on literature data, the uneven solute partitioning will increase with increasing tie-line length. ${ }^{22}$

Stability of the Anion Complexes. Partitioning experiments with $\left[\mathrm{Fe}(\mathrm{CN})_{5}(\mathrm{NO})\right]^{2-},\left[\mathrm{Mn}(\mathrm{CN})_{5}(\mathrm{NO})\right]^{3-}$, and $\left[\mathrm{Cr}(\mathrm{CN})_{5}(\mathrm{NO})\right]^{3-}$ anions were performed in the absence of light, so that the ions did not decompose. The anions stability was studied through electronic and infrared spectra in the top and bottom phases. In both cases the spectra obtained show that anion structure was not destroyed. In addition, elemental analysis confirmed that the $\left[\mathrm{Fe}(\mathrm{CN})_{5}(\mathrm{NO})\right]^{2-},\left[\mathrm{Mn}(\mathrm{CN})_{5}(\mathrm{NO})\right]^{3-}$, and $\left[\mathrm{Cr}(\mathrm{CN})_{5}(\mathrm{NO})\right]^{3-}$ anions did not decompose in the presence of the macromolecules used in this study.

Complex Partitioning Studies and the Influence of Central Metal. The partitioning behavior of the anion complex group, $\left[\mathrm{M}(\mathrm{CN})_{5} \mathrm{NO}\right]^{x-}$, was investigated in order to assess the effect of a small change in the complex structure, typically a change in the central atom $\mathrm{M}(\mathrm{M}=\mathrm{Fe}, \mathrm{Mn}$, or $\mathrm{Cr})$, and determine how this affects the thermodynamics of the anion transfer process.

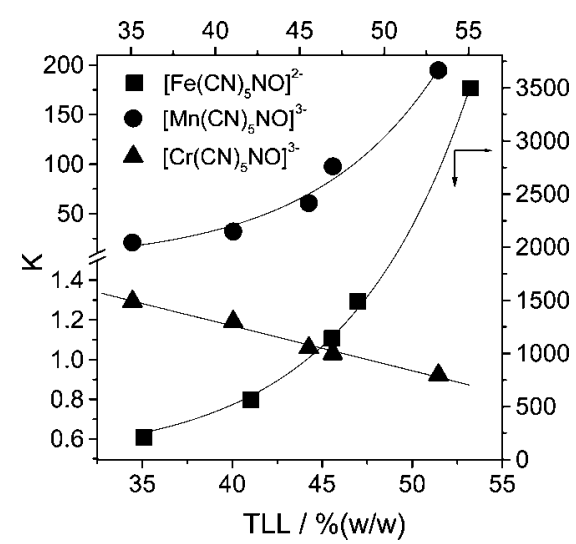

Figure 2. Partition coefficient $(K)$ versus tie-line length (TLL) in an ATPS formed with $\mathrm{PEO} / \mathrm{Li}_{2} \mathrm{SO}_{4} / \mathrm{H}_{2} \mathrm{O}$ at $298.15 \mathrm{~K}$ and pentacyanonitrosilmetallate complexes.

In very recently published papers, ${ }^{10,15}$ we reported that in ATPS without any added extractant there occurs a preferential transfer of the anion $\left[\mathrm{Fe}(\mathrm{CN})_{5} \mathrm{NO}\right]^{2-}$ from the salt-rich phase to the polymer-rich phase. In these investigations, we used ATPS formed with mixtures of aqueous solutions of PEO (MM $=3350$ and $\left.35000 \mathrm{~g} \mathrm{~mol}^{-1}\right)^{15}$ or triblock copolymers ( $\mathrm{L} 35=1900 \mathrm{~g}$ $\mathrm{mol}^{-1}$ and $\left.\mathrm{F} 68=8400 \mathrm{~g} \mathrm{~mol}^{-1}\right)^{23}$ with aqueous solutions of sulfate or phosphate salts $\left(\mathrm{Li}_{2} \mathrm{SO}_{4}, \mathrm{Na}_{2} \mathrm{SO}_{4}, \mathrm{MgSO}_{4}, \mathrm{Na}_{3} \mathrm{PO}_{4}\right)$. The partitioning behavior of the pentacyanonitrosilferrate has been attributed to a specific enthalpic interaction between the anion and EO macromolecular segments. The affinity of $\left[\mathrm{Fe}(\mathrm{CN})_{5} \mathrm{NO}\right]^{2-}$ with polymer molecules could be monitored by IR spectroscopy in view of the acceptor-donor interaction between the anion (mainly the $\mathrm{NO}^{+}$site) and macromolecules segments (due to the electronic pair found in the oxygen atom), which changes the NO electronic density and consequently the force constants of the $\mathrm{N}-\mathrm{O}$ bond. As the electronic densities of the NO group are very dependent on the nature of the complex central metal, ${ }^{24}$ we wanted to alter the PEO$\left[\mathrm{M}(\mathrm{CN})_{5} \mathrm{NO}\right]^{x-}$ interaction by replacing the iron atom present in the complex anion with manganese or chromium.

The complexes $\mathrm{Na}_{2}\left[\mathrm{Fe}(\mathrm{CN})_{5} \mathrm{NO}\right], \mathrm{K}_{3}\left[\mathrm{Mn}(\mathrm{CN})_{5} \mathrm{NO}\right]$, and $\mathrm{K}_{3}\left[\mathrm{Cr}(\mathrm{CN})_{5} \mathrm{NO}\right]$ were partitioned in 4 different temperatures $(278.15,298.15,308.15$, or $318.15 \mathrm{~K})$ in 12 distinct PEO/sulfate/ $\mathrm{H}_{2} \mathrm{O}$ systems. The following sulfate salts have been used $\mathrm{Na}_{2} \mathrm{SO}_{4}, \mathrm{Li}_{2} \mathrm{SO}_{4}, \mathrm{CuSO}_{4}$, and $\mathrm{ZnSO}_{4}$ with PEO $4000 \mathrm{~g} \mathrm{~mol}^{-1}$. Unfortunately, it was not possible to obtain $K$ values when using ATPS formed with PEO and $\mathrm{CuSO}_{4}$ because in all partitioning assays precipitation of the salt $\mathrm{Cu}_{x}\left[\mathrm{M}(\mathrm{CN})_{5} \mathrm{NO}_{2}\right.$ occurred.

Figure 2 shows the dependence of the partition coefficient, $K$, for all complexes with respect to TLL for ATPS formed with $\mathrm{PEO} / \mathrm{Li}_{2} \mathrm{SO}_{4} / \mathrm{H}_{2} \mathrm{O}$ at $298.15 \mathrm{~K}$.

It is clear from Figure 2 that slight differences in the complexes structures (change of central atom) promote very different partitioning behaviors. The pentacyanonitrosylferrate anion showed the highest affinity with the PEO-rich phase, reaching $K$ values as high as 3495 , while the $\left[\mathrm{Mn}(\mathrm{CN})_{5} \mathrm{NO}\right]^{3-}$ maximum partitioning coefficient value was 194 . On the other hand, pentacyanonitrosylcromate anion showed, for all TLL values, a partition coefficient around unity. Another important difference in the transfer process of these coordination compounds is that upon increasing the tie-line length the $K$ values of $\left[\mathrm{Fe}(\mathrm{CN})_{5} \mathrm{NO}\right]^{2-}$ and $\left[\mathrm{Mn}(\mathrm{CN})_{5} \mathrm{NO}\right]^{3-}$ increase while that of the $\left[\mathrm{Cr}(\mathrm{CN})_{5} \mathrm{NO}\right]^{3-}$ anion decreases.

The partitioning of these complex anions between two aqueous phases must be understood in terms of the molecular 


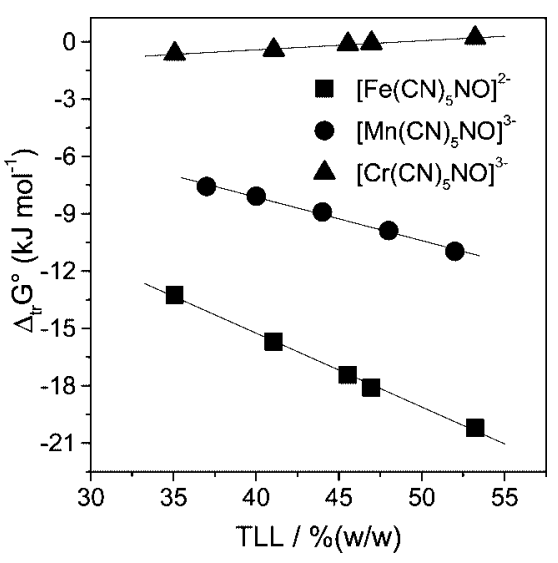

Figure 3. $\Delta_{\mathrm{tr}} G^{\circ}$ versus tie-line length (TLL) for complexes in an ATPS formed with $\mathrm{PEO} / \mathrm{Li}_{2} \mathrm{SO}_{4} / \mathrm{H}_{2} \mathrm{O}$ at $298.15 \mathrm{~K}$.

TABLE 1: Thermodynamic Parameters Obtained with the Nonlinear van't Hoff Equation for $\left[\mathrm{Mn}(\mathrm{CN})_{5}(\mathrm{NO})\right]^{3-}$ Anion in ATPS PEO/Na $\mathrm{Na}_{2}$

\begin{tabular}{|c|c|c|c|}
\hline$T / \mathrm{K}$ & $\Delta_{\mathrm{tr}} G^{\circ}\left(\mathrm{kJ} \mathrm{mol}^{-1}\right)$ & $\Delta_{\mathrm{tr}} H^{\circ}\left(\mathrm{kJ} \mathrm{mol}^{-1}\right)$ & $T \Delta_{\mathrm{tr}} S^{\circ}\left(\mathrm{kJ} \mathrm{mol}^{-1}\right)$ \\
\hline \multicolumn{4}{|c|}{ TLL 37\%(w/w) } \\
\hline 278 & -2.662 & -10.92 & -8.26 \\
\hline 298 & -2.018 & -12.16 & -10.14 \\
\hline 308 & -1.599 & -12.73 & -11.13 \\
\hline 318 & -1.350 & -13.25 & -11.90 \\
\hline \multicolumn{4}{|c|}{ TLL $40 \%(\mathrm{w} / \mathrm{w})$} \\
\hline 278 & -3.021 & -11.53 & -8.51 \\
\hline 298 & -2.267 & -14.25 & -11.98 \\
\hline 308 & -1.849 & -15.48 & -13.63 \\
\hline 318 & -1.453 & -16.63 & -15.18 \\
\hline \multicolumn{4}{|c|}{ TLL $44 \%(\mathrm{w} / \mathrm{w})$} \\
\hline 278 & 3.426 & -13.41 & -9.98 \\
\hline-298 & -2.521 & -16.46 & -13.94 \\
\hline 308 & -2.098 & -17.84 & -15.74 \\
\hline 318 & -1.586 & -19.13 & -17.54 \\
\hline \multicolumn{4}{|c|}{ TLL 48\%(w/w) } \\
\hline 278 & -3.831 & -15.73 & -11.90 \\
\hline 298 & -2.771 & -18.39 & -15.62 \\
\hline 308 & -2.355 & -19.58 & -17.23 \\
\hline 318 & -1.754 & -20.71 & -18.96 \\
\hline \multicolumn{4}{|c|}{ TLL $52 \%(\mathrm{w} / \mathrm{w})$} \\
\hline 278 & -4.266 & -19.15 & -14.88 \\
\hline 298 & -3.023 & -20.28 & -17.26 \\
\hline 308 & -2.605 & -20.79 & -18.18 \\
\hline 318 & -1.956 & -21.26 & -19.30 \\
\hline
\end{tabular}

interactions in the mixture. The polymer-polymer, polymersolvent, polymer-ion, and ion-ion interactions are functions of the polymers structures, the concentration of polymer and salt, the hydration of polymer chain in aqueous solution, and the valence and size of the ion. ${ }^{25}$ All interactions contribute to the thermodynamic parameter called transfer free energy, $\Delta_{\mathrm{tr}} G^{\mathrm{o}}$ $=-R T \ln K$.

Plots of $\Delta_{\mathrm{tr}} G^{\mathrm{o}}$ vs TLL for all complexes, in the ATPS formed with $\mathrm{PEO} / \mathrm{Li}_{2} \mathrm{SO}_{4} / \mathrm{H}_{2} \mathrm{O}$, are shown in Figure 3.

The transfer free energy of two complexes, $\left[\mathrm{Fe}(\mathrm{CN})_{5} \mathrm{NO}\right]^{2-}$ and $\left[\mathrm{Mn}(\mathrm{CN})_{5} \mathrm{NO}\right]^{3-}$, decreases linearly with increasing TLL values, while the transfer process of the anion $\left[\mathrm{Cr}(\mathrm{CN})_{5} \mathrm{NO}\right]^{3-}$ occurs with an increase in the free energy of the system or a very small decrease in the transfer thermodynamic parameter. In general, for ATPS formed with $\mathrm{PEO} / \mathrm{salt} / \mathrm{H}_{2} \mathrm{O}$, the distribution ratios for all ions investigated are low with values below unity. ${ }^{26}$ In this sense, the partitioning behavior of pentacyanonitrosylchromate anion is common, but the $\left[\mathrm{Fe}(\mathrm{CN})_{5} \mathrm{NO}\right]^{2-}$ and
TABLE 2: Thermodynamic Parameters Obtained with the Nonlinear van't Hoff Equation for $\left[\mathrm{Fe}(\mathrm{CN})_{5}(\mathrm{NO})\right]^{2-}$ Anion in ATPS PEO/Li $\mathrm{SO}_{4}$

\begin{tabular}{|c|c|c|c|}
\hline$T / \mathrm{K}$ & $\Delta_{\mathrm{tr}} G^{\circ}\left(\mathrm{kJ} \mathrm{mol}^{-1}\right)$ & $\Delta_{\mathrm{tr}} H^{\circ}\left(\mathrm{kJ} \mathrm{mol}^{-1}\right)$ & $T \Delta_{\mathrm{tr}} S^{\circ}\left(\mathrm{kJ} \mathrm{mol}^{-1}\right)$ \\
\hline \multicolumn{4}{|c|}{ TLL $37 \%(\mathrm{w} / \mathrm{w})$} \\
\hline 278 & -17.03 & -78.10 & -61.07 \\
\hline 298 & -13.45 & -51.30 & -37.85 \\
\hline 308 & -12.71 & -39.20 & -26.49 \\
\hline 318 & -11.75 & -27.80 & -16.05 \\
\hline \multicolumn{4}{|c|}{ TLL $40 \%(\mathrm{w} / \mathrm{w})$} \\
\hline 278 & -18.02 & -56.20 & -38.18 \\
\hline 298 & -14.73 & -54.90 & -40.17 \\
\hline 308 & -14.69 & -54.30 & -39.61 \\
\hline 318 & -12.31 & -53.70 & -41.39 \\
\hline \multicolumn{4}{|c|}{ TLL $43 \%(\mathrm{w} / \mathrm{w})$} \\
\hline 278 & -18.73 & -31.30 & -12.57 \\
\hline 298 & -16.35 & -55.60 & -39.25 \\
\hline 308 & -16.16 & -66.60 & -50.44 \\
\hline 318 & -13.24 & -76.90 & -63.66 \\
\hline \multicolumn{4}{|c|}{ TLL $46 \%(\mathrm{w} / \mathrm{w})$} \\
\hline 278 & -19.28 & -11.90 & 7.38 \\
\hline 298 & -17.76 & -54.70 & -36.94 \\
\hline 308 & -17.33 & -74.00 & -56.67 \\
\hline 318 & -14.24 & -92.10 & -77.86 \\
\hline \multicolumn{4}{|c|}{ TLL $49 \%(\mathrm{w} / \mathrm{w})$} \\
\hline 278 & -19.74 & -21.82 & -2.08 \\
\hline 298 & -18.91 & -52.90 & -33.99 \\
\hline 308 & -18.27 & -77.70 & -59.43 \\
\hline 318 & -15.19 & -101.0 & -85.81 \\
\hline
\end{tabular}

TABLE 3: Thermodynamic Parameters Obtained with the Nonlinear van't Hoff Equation for $\left[\mathrm{Fe}(\mathrm{CN})_{5}(\mathrm{NO})\right]^{2-}$ Anion in ATPS PEO/Na ${ }_{2} \mathrm{SO}_{4}$

\begin{tabular}{cccc}
\hline$T / \mathrm{K}$ & $\Delta_{\mathrm{tr}} G^{\circ}\left(\mathrm{kJ} \mathrm{mol}^{-1}\right)$ & $\Delta_{\mathrm{tr}} H^{\circ}\left(\mathrm{kJ} \mathrm{mol}^{-1}\right)$ & $T \Delta_{\mathrm{tr}} S^{\circ}\left(\mathrm{kJ} \mathrm{mol}^{-1}\right)$ \\
\hline & & $\mathrm{TLL} 30 \%(\mathrm{w} / \mathrm{w})$ & \\
278 & -8.59 & -30.90 & -22.31 \\
298 & -7.75 & -10.60 & -2.85 \\
308 & -7.73 & -1.48 & 6.25 \\
318 & -8.13 & 7.09 & 15.22 \\
& & $\mathrm{TLL} 33 \%(\mathrm{w} / \mathrm{w})$ & \\
278 & -9.79 & -32.50 & -22.71 \\
298 & -8.77 & -14.00 & -5.23 \\
308 & -8.84 & -5.70 & 3.14 \\
318 & -8.98 & 2.10 & 11.08 \\
& & $\mathrm{TLL} 36 \%(\mathrm{w} / \mathrm{w})$ & \\
278 & -10.76 & -32.50 & -21.74 \\
298 & -9.70 & -16.00 & -6.30 \\
308 & -9.82 & -8.52 & 1.30 \\
318 & -9.80 & -1.54 & 8.26 \\
& & $\mathrm{TLL} 39 \%(\mathrm{w} / \mathrm{w})$ & \\
278 & -11.56 & -32.50 & -20.94 \\
298 & -10.50 & -16.60 & -6.10 \\
308 & -10.69 & -9.37 & 1.32 \\
318 & -10.61 & -2.64 & 7.97 \\
& & $\mathrm{TLL} 42 \%(\mathrm{w} / \mathrm{w})$ & -21.55 \\
278 & -12.25 & -33.80 & -5.00 \\
298 & -11.20 & -16.20 & 3.13 \\
308 & -11.45 & -8.32 &
\end{tabular}

$\left[\mathrm{Mn}(\mathrm{CN})_{5} \mathrm{NO}\right]^{3-}$ concentration on the top phase suggests the existence of a special driving power.

Following Johansson et al., ${ }^{27}$ the preferential concentration of $\left[\mathrm{Cr}(\mathrm{CN})_{5} \mathrm{NO}\right]^{3-}$ in the salt-rich phase could be attributed to two factors. First, an entropic driving power, which arises from the fact that there is a difference between the top and bottom 
phases with regard to the number of molecules per unit volume. This entropic contribution is expressed by eq 4

$$
\ln K=\frac{M}{\rho}\left(\frac{n^{\mathrm{T}}}{V^{\mathrm{T}}}-\frac{n^{\mathrm{B}}}{V^{\mathrm{B}}}\right)
$$

where $M$ is the molar mass of the partitioning solute, $n^{\mathrm{T}}$ and $n^{\mathrm{B}}$ are the total number of molecules in the top and bottom phase, respectively, which generate a phase number density when divided by the respective phase volume, $V^{\mathrm{T}}$ or $V^{\mathrm{B}}$, and $\rho$ is the number of lattice sites per unit volume.

In $\mathrm{PEO} / \mathrm{M}_{x} \mathrm{SO}_{4} / \mathrm{H}_{2} \mathrm{O}$ ATPS, the bottom phase has the highest number density due to the higher water content of the salt-rich phase. As is well known, the mixing entropy increases in proportion to the natural logarithm of the number of distinguishable ways in which the molecules in the mixture can be arranged. In association with the entropic drive, there could be an enthalpic contribution to the $\left[\mathrm{Cr}(\mathrm{CN})_{5} \mathrm{NO}\right]^{3-}$ uneven distribution caused by electrostatic interactions between the ATPSforming salt ions and $\left[\mathrm{Cr}(\mathrm{CN})_{5} \mathrm{NO}^{3-}\right.$. This contribution is expressed by the term $\left[\sum_{i=1(i \neq S)}^{m}\left(\Phi_{i}^{\mathrm{T}}-\Phi_{i}^{\mathrm{B}}\right) w_{N P_{-i}}\right]$ in eq 5

$$
\begin{aligned}
& \ln K=-\frac{M_{\mathrm{S}}}{R T}\left[\sum_{i=1(i \neq S)}^{m}\left(\Phi_{i}^{\mathrm{T}}-\Phi_{i}^{\mathrm{B}}\right) w_{\mathrm{NP}-i}-\right. \\
& \left.\qquad \sum_{i=1}^{2} \sum_{j=2}^{3}\left(\Phi_{i}^{\mathrm{T}} \Phi_{j}^{\mathrm{T}}-\Phi_{i}^{\mathrm{B}} \Phi_{j}^{\mathrm{B}}\right) w_{i-j}\right]
\end{aligned}
$$

The stronger the ion $-\left[\mathrm{Cr}(\mathrm{CN})_{5} \mathrm{NO}\right]^{3-}$ interaction, i.e, the more negative is $w_{\mathrm{NP}-i}$, the more enthalpically favorable will be the transfer of the anion to the phase enriched in the ions component. In eq $5, \Phi_{i}^{\mathrm{T}}$ and $\Phi_{i}^{\mathrm{B}}$ are the volume fractions of the component " $i$ " in the top and bottom phases, respectively; $w_{i j}$ is the effective pairwise interchange energy defined as $w_{i j}=z\left[\varepsilon_{i j}-1 / 2\left(\varepsilon_{i i}+\varepsilon_{j j}\right)\right]$, $z$ is the number of nearest neighbors, and $\varepsilon_{i j}$ is the potential energy of an $i-j$ pair. The second term on the right-hand side of eq 5 quantifies the difference in energy of each phase (phase self-energy) due to unlike enthalpic interactions between all phase components other than complex anion. The dependence of $K$ values on the self-energies of the top and bottom phases arises because insertion of the complex anion into a phase requires breaking interactions between components of the phase to create a cavity into which the $\left[\mathrm{M}(\mathrm{CN})_{5} \mathrm{NO}\right]^{x-}$ fits. Da Silva et al. ${ }^{15}$ demonstrated that the phase self-energy does not does contribute very much to the partitioning behavior of the anion complex with chemical structures like $\left[\mathrm{M}(\mathrm{CN})_{5} \mathrm{NO}\right]^{x-}$.

On the other hand, still based on the Johansson model, $\left[\mathrm{Fe}(\mathrm{CN})_{5} \mathrm{NO}\right]^{2-}$ and $\left[\mathrm{Mn}(\mathrm{CN})_{5} \mathrm{NO}\right]^{3-}$ spontaneous transfer from the bottom phase to the top phase may be only attributed to a specific enthalpic interaction between these complex anions with the EO segments of the macromolecular chains, which concentrate in the top phase. In view of this, the observed $K$ values trend, $\left[\mathrm{Fe}(\mathrm{CN})_{5} \mathrm{NO}\right]^{2-}>\left[\mathrm{Mn}(\mathrm{CN})_{5} \mathrm{NO}\right]^{3-}>\left[\mathrm{Cr}(\mathrm{CN})_{5} \mathrm{NO}\right]^{3-}$, should follow the same order as the magnitude of the molecular interaction between each complex and the EO segments.

It is clear from the discussion above that the nature of the central metal $(\mathrm{M}=\mathrm{Fe}, \mathrm{Mn}, \mathrm{Cr})$ in the $\left[\mathrm{M}(\mathrm{CN})_{5} \mathrm{NO}\right]^{x-}$ structure has a very strong influence on the anion-EO interaction and consequently on the complex partitioning behavior. To make clear the molecular source of this different interaction, electronic analysis of the coordination complexes should be performed. All complexes have several common features. For example, a theoretical approach indicated that the levels of the nitrosyl group are substantially lower than their cyanide similar energy state. However, It is well known that there are intramolecular

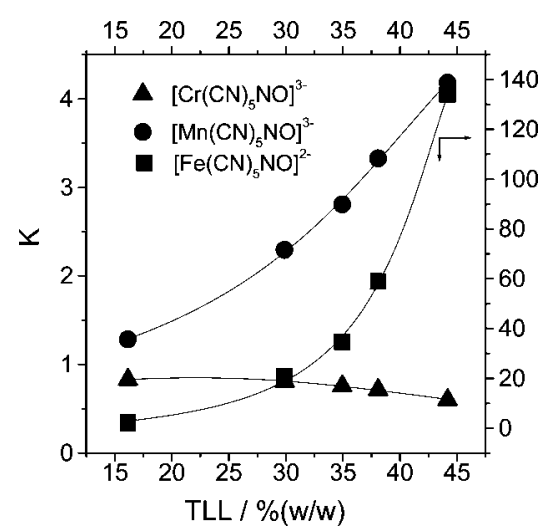

Figure 4. Partition coefficient versus tie-line length in an ATPS formed with $\mathrm{PEO} / \mathrm{Na}_{2} \mathrm{SO}_{4} / \mathrm{H}_{2} \mathrm{O}$ at $298.15 \mathrm{~K}$ and pentacyanonitrosylmetallate complexes.

environmental effects, caused by the central atom, in the energy levels and electronic distributions, ${ }^{28}$ as illustrated by the fact that the magnitudes of the separations are not nearly as large as those in the isolated ligands $\left(\mathrm{CN}^{-}\right.$and $\left.\mathrm{NO}^{+}\right)$. This alteration reflects the loss of electron density of the $\mathrm{CN}^{-}$group and accumulation of electron density of the $\mathrm{NO}^{+}$upon complex formation. ${ }^{29}$ Appropriate calculations, which make use of a Mulliken population analysis, ${ }^{30}$ found that for both the cyanide and the nitrosyl ligands the electronic structures of the $3 \sigma, 4 \sigma$, and $1 \pi$ orbitals were unchanged as compared with those of the free ions. Only the $5 \sigma$ and $2 \pi$ orbital occupancies appear to be affected by complex formation. Molecular orbital calculations show that in $\left[\mathrm{Fe}(\mathrm{CN})_{5} \mathrm{NO}\right]^{2-}$ the metal $3 \mathrm{~d}$ level is about $5 \mathrm{eV}$ below that of the $2 \pi \mathrm{NO}^{+}$and approximately the same as that of the $5 \sigma \mathrm{CN}^{-}$, but when a proton is removed from the pentacyanitrosylferrate anion, thus forming the $\left[\mathrm{Mn}(\mathrm{CN})_{5} \mathrm{NO}\right]^{3-}$ complex, there occurs destabilization of the metal levels and a decrease in the difference between the metal $3 \mathrm{~d}$ and $2 \pi \mathrm{NO}^{+}$ levels from 5 to $2 \mathrm{eV}$. In addition, as a consequence of proton withdrawal and electron addition, $\left[\mathrm{Mn}(\mathrm{CN})_{5} \mathrm{NO}\right]^{3-}$ is converted into $\left[\mathrm{Cr}(\mathrm{CN})_{5} \mathrm{NO}\right]^{3-}$, which increases the molecular orbital destabilization and consequently decreases the $3 \mathrm{~d}$ and $2 \pi\left(\mathrm{NO}^{+}\right)$ energy difference. This metal effect has two major consequences. First, the $\sigma$ donation of a cyanide group should be greater than that of the nitrosyl group. Second, variations in the metal $3 \mathrm{~d}$ levels should result in substantial fluctuations in the degree of $\sigma$ donation by cyanides but cause only minor changes in that of the nitrosyl group. The converse holds true for the $2 \pi$ orbital interactions. In summary, the calculations predicted that as a result of metal replacement from iron to manganese to chromium there is an increase in the $\mathrm{NO}^{+}$ electronic density, mainly due to formation of $\pi$ bonds, which impairs the tendency of the complex to interact (acceptor-donor interaction) with electronic pairs present in the oxygen atoms of the ethylene-oxide segment. Naturally, no claim is made for the absolute accuracy of the state energy values obtained in this kind of theoretical calculation. However, we do assert that relative trends are meaningful and give insight into the effect of the central atom on the electronic structures of the species.

Salt Effects in the $\left[\mathrm{M}(\mathrm{CN})_{5} \mathrm{NO}^{\mathrm{x}}{ }^{-}\right.$Partitioning Behavior. The same relative partitioning behavior for the three complex anions, i.e, $K_{\left[\mathrm{Fe}(\mathrm{CN})_{5} \mathrm{NO}_{2-}-\right.} \gg K_{\left[\mathrm{Mn}(\mathrm{CN})_{5} \mathrm{NO}\right]^{3-}}>K_{\left[\mathrm{Cr}(\mathrm{CN})_{5} \mathrm{NO}_{3}^{3-}\right.}$, was observed when the lithium sulfate was replaced with $\mathrm{Na}_{2} \mathrm{SO}_{4}$ (Figure 4). However, for a specific complex the $K$ values obtained in $\mathrm{PEO} / \mathrm{Li}_{2} \mathrm{SO}_{4} / \mathrm{H}_{2} \mathrm{O}$ ATPS are even higher than the partitioning coefficients found in the $\mathrm{PEO} / \mathrm{Na}_{2} \mathrm{SO}_{4} / \mathrm{H}_{2} \mathrm{O}$ ATPS.

In the $\mathrm{PEO} / \mathrm{ZnSO}_{4} / \mathrm{H}_{2} \mathrm{O}$ ATPS, $\left[\mathrm{Fe}(\mathrm{CN})_{5} \mathrm{NO}^{2-}\right.$ and $[\mathrm{Cr}-$ $(\mathrm{CN})_{5} \mathrm{NO}^{3-}$ concentrate in the top phase at an almost similar 


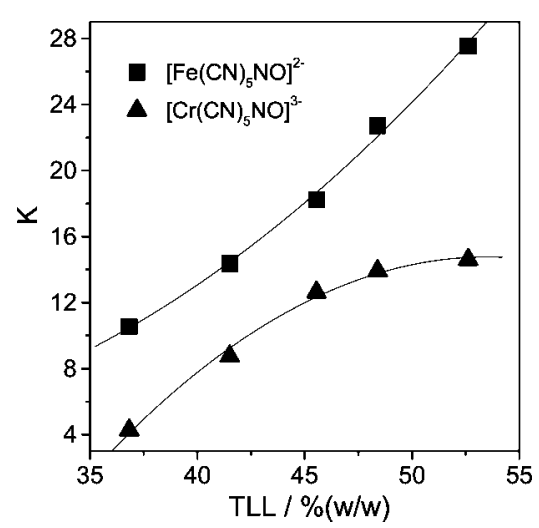

Figure 5. Partition coefficient versus tie-line length in an ATPS formed with $\mathrm{PEO} / \mathrm{ZnSO}_{4} / \mathrm{H}_{2} \mathrm{O}$ at $298.15 \mathrm{~K}$ and pentacyanonitrosylmetallate complexes.

extent (Figure 5) while the $\left[\mathrm{Mn}(\mathrm{CN})_{5} \mathrm{NO}\right]^{3-}$ anion precipitates at the interface as $\mathrm{Zn}_{3}\left[\mathrm{Mn}(\mathrm{CN})_{5} \mathrm{NO}\right]_{2}$.

The effect of the electrolyte nature in the free energy of transfer is depicted in Figure 6, showing the plots of $\Delta_{\mathrm{tr}} G^{\mathrm{o}}$ vs TLL for all complexes, in the ATPS formed with PEO/ $\mathrm{Na}_{2} \mathrm{SO}_{4} /$ $\mathrm{H}_{2} \mathrm{O}$ and $\mathrm{PEO} / \mathrm{ZnSO}_{4} / \mathrm{H}_{2} \mathrm{O}$.

Similarly to the ATPS formed with $\mathrm{Li}_{2} \mathrm{SO}_{4}$, in the PEO/ $\mathrm{Na}_{2} \mathrm{SO}_{4} / \mathrm{H}_{2} \mathrm{O}$ system the transfer free energy of two complexes, $\left[\mathrm{Fe}(\mathrm{CN})_{5} \mathrm{NO}\right]^{2-}$ and $\left[\mathrm{Mn}(\mathrm{CN})_{5} \mathrm{NO}\right]^{3-}$, decreases linearly with increasing TLL values while the transfer process of the anion $\left[\mathrm{Cr}(\mathrm{CN})_{5} \mathrm{NO}\right]^{3-}$ occurs with increasing free energy of the system. The $\Delta_{\mathrm{tr}} G^{\mathrm{o}}$ values were very dependent on the electrolyte nature, following the orders as follows: for $\Delta_{\mathrm{tr}} G_{\mathrm{Fe}}^{\mathrm{o}}, \mathrm{Li}_{2} \mathrm{SO}_{4}<$ $\mathrm{Na}_{2} \mathrm{SO}_{4}<\mathrm{ZnSO}_{4} ; \Delta_{\mathrm{tr}} G_{\mathrm{Mn}}^{\mathrm{o}}, \mathrm{Li}_{2} \mathrm{SO}_{4}<\mathrm{Na}_{2} \mathrm{SO}_{4}$; for $\Delta_{\mathrm{tr}} G_{\mathrm{Cr}}^{\mathrm{o}}$, $\mathrm{Zn}_{2} \mathrm{SO}_{4}<\mathrm{Na}_{2} \mathrm{SO}_{4}<\mathrm{Li}_{2} \mathrm{SO}_{4}$. As can be seen from Figure 6, the electrolyte effect is weaker than the central metal influence.

As reported in previously published papers, ${ }^{7,10,15}$ the salt effect in the pentacyanonitrosylmetallate partitioning behavior could be attributed to an interaction between salt cations and the PEO macromolecules, resulting in a positively charged polymer surface (pseudopolication), which can interact with the $\left[\mathrm{M}(\mathrm{CN})_{5} \mathrm{NO}\right]^{x-}$ anion. According to this approach, the cation of the ATPS salt component plays an important role by simultaneously interacting with complex anions and PEO. The increase in PEO- $\left[\mathrm{M}(\mathrm{CN})_{5} \mathrm{NO}\right]^{x-}$ interaction, when sodium cation is replaced with $\mathrm{Li}^{+}$, can be explained by both of the following two ideas: (i) the number of $\mathrm{Li}^{+}$ions bound to polymer chains is larger than that of $\mathrm{Na}^{+}$ions, resulting in higher positive charge density and (ii) the electrostatic interaction between $\mathrm{EO}-\mathrm{Li}^{+}-\left[\mathrm{M}(\mathrm{CN})_{5} \mathrm{NO}\right]^{x-}$ is more intense than that of $\mathrm{EO}-\mathrm{Na}^{+}-\left[\mathrm{M}(\mathrm{CN})_{5} \mathrm{NO}\right]^{x-}$.

Temperature Effect on Partitioning. Analysis of $\Delta_{\mathrm{tr}} G^{\mathrm{o}}$ parameters in terms of molecular processes is hard because they contain one molecular interaction parameter, $\Delta_{\mathrm{tr}} H^{\circ}$, and one configuration variable, $\Delta_{\mathrm{tr}} S^{0}$, both depicted in terms of criteria specified by the Gibbs - Helmoholtz relationship, namely, $\Delta_{\mathrm{tr}} G^{\mathrm{o}}$ $=\Delta_{\mathrm{tr}} H^{\mathrm{o}}-T \Delta_{\mathrm{tr}} S^{\mathrm{o}}$. The values of the enthalpy of transfer can be derived from data referring to the temperature dependence of the partition coefficients, generally interpreted by means of the linear van't Hoff equations. ${ }^{31}$ Figures 7, 8, and 9 show van't Hoff plots of $\ln K$ versus $1 / T$ for complexes of iron, manganese, and chromium, respectively, in ATPS formed with $\mathrm{Na}_{2} \mathrm{SO}_{4} / \mathrm{PEO} /$ $\mathrm{H}_{2} \mathrm{O}$.

All curves shown are nonlinear, indicating that the enthalpy of transfer varies with temperature and consequently the transfer heat capacity change, $\Delta_{\mathrm{tr}}^{\mathrm{o}} C p=\left(\delta \Delta \operatorname{tr} H^{\circ} / \delta T\right)$, is not zero. This leads to curvatures in the van't Hoff plots. If these plots are nonlinear, the tangent to the curve at any point along the curve is $\Delta \operatorname{tr} H^{\circ}$ at that temperature. Recent studies ${ }^{32}$ on a variety of systems have shown that assumption of linear van't Hoff plots is frequently incorrect, and for analysis of the complete van't Hoff curve in such cases, more elaborate models must then be used when attempts to extract reliable estimates of $\Delta \operatorname{tr} H^{\circ}$ are made.

In order to obtain the transfer enthalpic and entropic parameters we applied eqs 6,7 , and 8

$$
\begin{gathered}
\ln K_{i}=a+b(1 / T)+c(1 / T)^{2}+d(1 / T)^{3}+\ldots+\ln \Phi \\
\Delta_{\mathrm{tr}} H^{o}=-R\left[b+2 c(1 / T)+3 d(1 / T)^{2}+\ldots\right] \\
\Delta_{\mathrm{tr}} S^{\mathrm{o}}=\frac{\left(\Delta_{\mathrm{tr}} H^{\mathrm{o}}-\Delta_{\mathrm{tr}} G^{\mathrm{o}}\right)}{T}
\end{gathered}
$$

Figure 10 shows the enthalpy of transfer vs temperature for $\left[\mathrm{Mn}(\mathrm{CN})_{5} \mathrm{NO}^{3-}\right.$ complexes partitioned in ATPS formed with $\mathrm{PEO} / \mathrm{Li}_{2} \mathrm{SO}_{4} / \mathrm{H}_{2} \mathrm{O}$. Similar behaviors were obtained for the other complexes and ATPS systems studied in this work (Tables 1 to 7). On the basis of the nonlinear van't Hoff approach, the transfer enthalpy values of $\left[\mathrm{Fe}(\mathrm{CN})_{5} \mathrm{NO}\right]^{2-},\left[\mathrm{Mn}(\mathrm{CN})_{5} \mathrm{NO}\right]^{3-}$, and $\left[\mathrm{Cr}(\mathrm{CN})_{5} \mathrm{NO}\right]^{3-}$ anions become more negative as temperature and TLL magnitude increase. The transfer processes of these coordination compounds are ever exothermic, but their magnitudes depend on the nature of the central atom, following the order $\left[\mathrm{Fe}(\mathrm{CN})_{5} \mathrm{NO}^{2-}<\left[\mathrm{Mn}(\mathrm{CN})_{5} \mathrm{NO}\right]^{3-}<\left[\mathrm{Cr}(\mathrm{CN})_{5^{-}}\right.\right.$ $\mathrm{NO}]^{3-}$. Surprisingly, for $\left[\mathrm{Fe}(\mathrm{CN})_{5} \mathrm{NO}\right]^{2-}$ anion in the $\mathrm{PEO} /$ $\mathrm{Na}_{2} \mathrm{SO}_{4}$ ATPS systems (TLL $=30 \%$ or $33 \% \mathrm{w} / \mathrm{w}$ ) and at 318 $\mathrm{K}$ the trasnsfer process was endothermic and entropically driven. It was not possible for us to find a scientific explanation for these exceptions.

In order to analyze the complete effect of temperature in the transfer process, it is necessary to examine the temperature dependence of $\Delta_{\mathrm{tr}} G^{\mathrm{o}}$ and $\Delta_{\mathrm{tr}} \mathrm{S}^{\mathrm{o}}$. The relationship between the free energy of transfer or the entropy of transfer and the temperature is shown in Figures 11 and 12, respectively. Both thermodynamic parameters were plotted for $\left[\mathrm{Mn}(\mathrm{CN})_{5} \mathrm{NO}\right]^{3-}$ anion in the $\mathrm{PEO} / \mathrm{Li}_{2} \mathrm{SO}_{4} / \mathrm{H}_{2} \mathrm{O}$ ATPS. Equivalent results are obtained for the other complexes in different ATPS and shown in Tables 1 to 7.

The complexes affinities with the top phase, at any TLL value, decrease with increasing temperature, regardless of the fact that the enthalpy of transfer becomes more negative with increasing temperature. As shown in Figures 10 and 12, the temperature effect on the partitioning behavior should be attributed to a proportional decrease of enthalpy and entropy of transfer with the temperature increase. However, for the temperature range investigated, the transfer of all complexes anions is enthalpically driven. In each temperature and for all ATPS, the thermodynamic transfer behavior of the three pentacyanonitrosylmetallate complexes satisfies the criteria of entropy-enthalpy compensation, as confirmed by the linear relationship of the plot $\Delta_{\mathrm{tr}} S^{\mathrm{o}}$ versus $\Delta_{\mathrm{tr}} H^{\circ}$, as illustrated by Figure 13 for the anion $\left[\mathrm{Fe}(\mathrm{CN})_{5} \mathrm{NO}\right]^{2-}$ in the ATPS PEO/Li $\mathrm{SO}_{4} / \mathrm{H}_{2} \mathrm{O}$.

The entropy-enthalpy compensation behavior, observed in the complexes transfer process, should be ascribed to the following mechanism: when $\left[\mathrm{M}(\mathrm{CN})_{5} \mathrm{NO}\right]^{x-}$ anion is transferred from the bottom phase to the top phase, the anion and the EO segment interact, releasing some water molecules that were solvating them. The more negative the transfer enthalpy becomes, the more intense the $\mathrm{EO}-\left[\mathrm{M}(\mathrm{CN})_{5} \mathrm{NO}^{\mathrm{x}-}\right.$ interaction and consequently more water molecules are released. Some of 

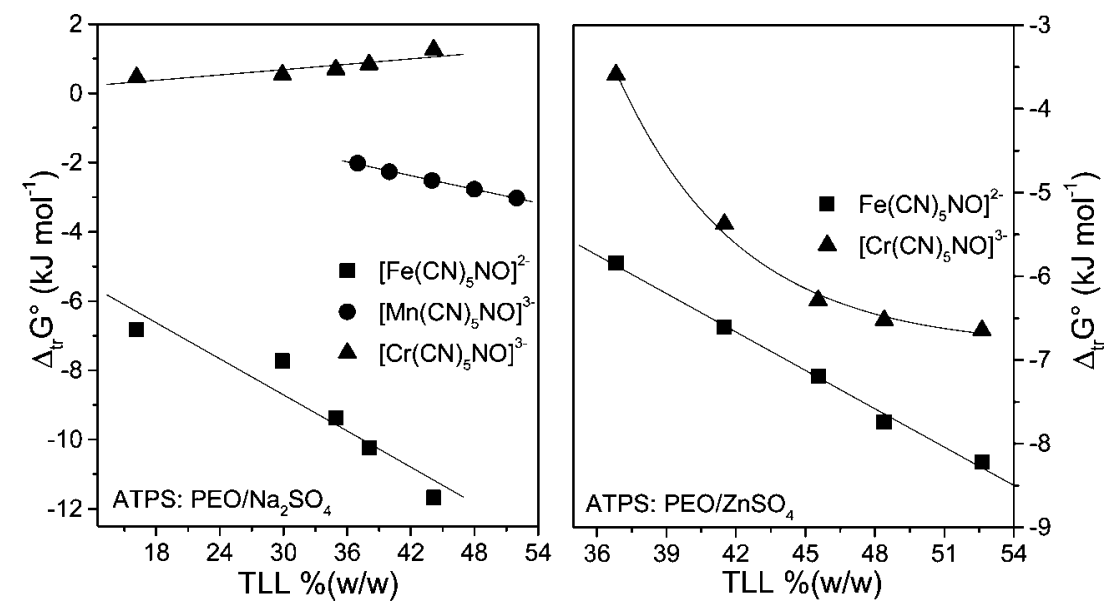

Figure 6. $\Delta_{\mathrm{tr}} G^{\circ}$ versus tie-line length for complexes in an ATPS formed with PEO/sulphates/ $\mathrm{H}_{2} \mathrm{O}$ at $298.15 \mathrm{~K}$.

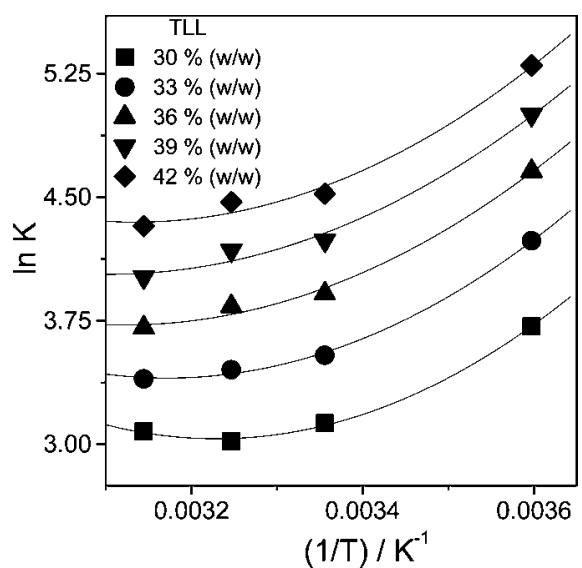

Figure 7. Plot of $\ln K$ versus $1 / T$ for the complex $\left[\mathrm{Fe}(\mathrm{CN})_{5} \mathrm{NO}\right]^{2-}$ in an ATPS formed with $\mathrm{Na}_{2} \mathrm{SO}_{4} / \mathrm{PEO} / \mathrm{H}_{2} \mathrm{O}$ in four different temperatures with five tie-line lengths (TLL).

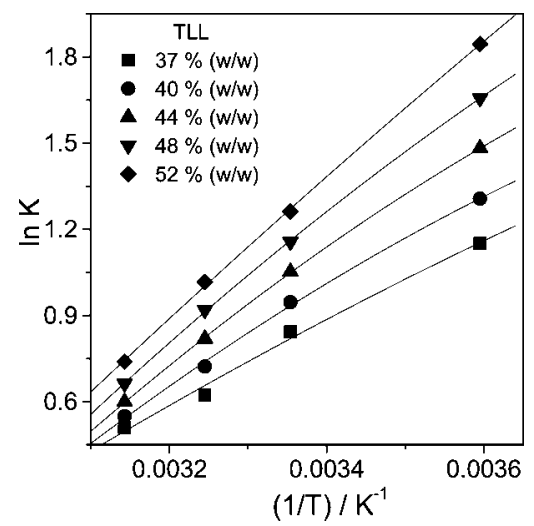

Figure 8. Plot of $\ln K$ versus $1 / T$ for the complex $\left[\mathrm{Mn}(\mathrm{CN})_{5} \mathrm{NO}\right]^{3-}$ in an ATPS formed with $\mathrm{PEO} / \mathrm{Na}_{2} \mathrm{SO}_{4}$ in four different temperatures with five tie-line lengths (TLL).

these water molecules spontaneously transfer from the top phase to the bottom phase, thus decreasing the entropy of transfer (eq 4).

In many cases where an unusually large $\Delta C_{p}^{0}$ temperature dependence is involved, van't Hoff enthalpy change, $\Delta_{\mathrm{tr}} H^{\circ}{ }_{\mathrm{vH}}$, and the directly observed calorimetric enthalpy change, $\Delta_{\mathrm{tr}} H_{\text {cal }}^{\mathrm{H}}$, do not agree. Then, to reveal a possible difference between $\Delta_{\mathrm{tr}} H^{\circ}{ }_{\mathrm{vH}}$ and $\Delta_{\mathrm{tr}} H^{\mathrm{o}}$ cal associated with the $\left[\mathrm{M}(\mathrm{CN})_{5} \mathrm{NO}\right]^{x-}$ anion partitioning process, calorimetric measurements were carried out. Figure 14 shows a comparison between $\Delta_{\mathrm{tr}} H^{\mathrm{o}}$ cal and $\Delta_{\mathrm{tr}} H_{\mathrm{vH}}^{\mathrm{o}}$

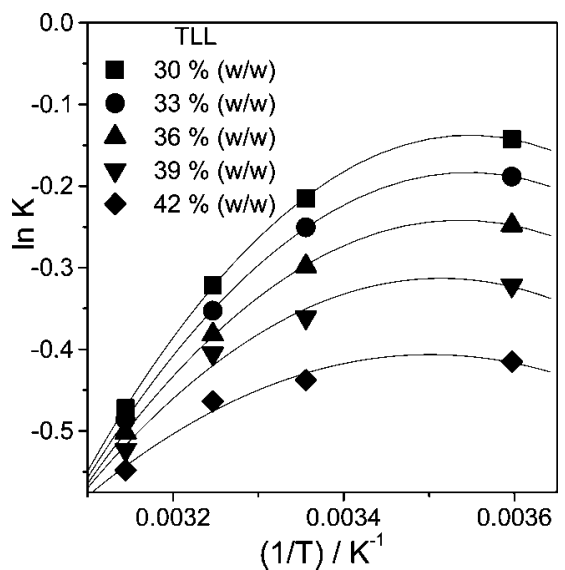

Figure 9. Plot of $\ln K$ verus $1 / T$ for the complex $\left[\mathrm{Cr}(\mathrm{CN})_{5} \mathrm{NO}\right]^{3-}$ in an ATPS formed with $\mathrm{Na}_{2} \mathrm{SO}_{4} / \mathrm{PEO} / \mathrm{H}_{2} \mathrm{O}$ in four different temperatures with five tie-line lengths (TLL).

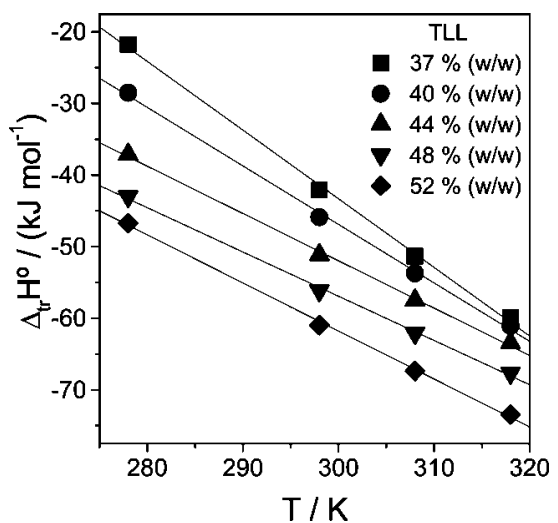

Figure 10. Transfer enthalpy vs temperature for the complex $\left[\mathrm{Mn}(\mathrm{CN})_{5} \mathrm{NO}\right]^{3-}$ in the $\mathrm{PEO} / \mathrm{Li}_{2} \mathrm{SO}_{4} / \mathrm{H}_{2} \mathrm{O}$ ATPS.

obtained for the PEO/ $\mathrm{Na}_{2} \mathrm{SO}_{4} / \mathrm{H}_{2} \mathrm{O}$ ATPS systems, where both enthalpies were plotted versus TLL.

For all complexes significant differences between the calorimetric and van't Hoff enthalpies were found to exist. For $\left[\mathrm{Cr}(\mathrm{CN})_{5} \mathrm{NO}\right]^{3-}, \Delta_{\mathrm{tr}} H^{\mathrm{o}}$ cal results show that anion transfer, from the bottom phase to the top phase, is an endothermic process, which makes the anion concentration on the polymer-enriched phase thermodynamically unfavorable (enthalpically and entropically).

If $\Delta_{\mathrm{tr}} H_{\mathrm{vH}}^{\mathrm{o}}=\Delta_{\mathrm{tr}} H^{\mathrm{o}}$ cal, the thermodynamic changes should be regarded as a two-state process with an infinite entropy 
TABLE 4: Thermodynamic Parameters Obtained with the Nonlinear van't Hoff Equation for $\left[\mathrm{Fe}(\mathrm{CN})_{5}(\mathrm{NO})\right]^{2-}$ Anion in ATPS PEO/ZnSO

\begin{tabular}{|c|c|c|c|}
\hline$T / \mathrm{K}$ & $\Delta_{\mathrm{tr}} G^{\circ}\left(\mathrm{kJ} \mathrm{mol}^{-1}\right)$ & $\Delta_{\mathrm{tr}} H^{\circ}\left(\mathrm{kJ} \mathrm{mol}^{-1}\right)$ & $T \Delta_{\mathrm{tr}} S^{\circ}\left(\mathrm{kJ} \mathrm{mol}^{-1}\right)$ \\
\hline \multicolumn{4}{|c|}{ TLL 37\%(w/w) } \\
\hline 278 & -7.51 & -31.90 & -24.39 \\
\hline 298 & -5.89 & -23.90 & -18.01 \\
\hline 308 & -5.50 & -20.30 & -14.80 \\
\hline 318 & -5.44 & -16.90 & -11.46 \\
\hline \multicolumn{4}{|c|}{ TLL $40 \%(\mathrm{w} / \mathrm{w})$} \\
\hline 278 & -8.13 & -32.70 & -24.57 \\
\hline 298 & -6.33 & -26.90 & -20.57 \\
\hline 308 & -6.03 & -24.40 & -18.37 \\
\hline 318 & -5.53 & -21.90 & -16.37 \\
\hline \multicolumn{4}{|c|}{ TLL 43\%(w/w) } \\
\hline 278 & -9.03 & -37.50 & -28.47 \\
\hline 298 & -6.86 & -31.60 & -24.74 \\
\hline 308 & -6.56 & -28.90 & -22.34 \\
\hline 318 & -5.68 & -26.40 & -20.72 \\
\hline \multicolumn{4}{|c|}{ TLL 46\%(w/w) } \\
\hline 278 & -10.38 & -48.70 & -38.32 \\
\hline 298 & -7.35 & -39.40 & -32.05 \\
\hline 308 & -7.16 & -35.20 & -28.04 \\
\hline 318 & -5.96 & -31.20 & -25.24 \\
\hline \multicolumn{4}{|c|}{ TLL 49\%(w/w) } \\
\hline 278 & -12.24 & -75.20 & -62.96 \\
\hline 298 & -7.81 & -48.40 & -40.59 \\
\hline 308 & -7.70 & -36.30 & -28.60 \\
\hline 318 & -6.61 & -25.00 & -18.39 \\
\hline
\end{tabular}

TABLE 5: Thermodynamic Parameters Obtained with the Nonlinear van't Hoff Equation for $\left[\mathrm{Cr}(\mathrm{CN})_{5} \mathrm{NO}\right]^{3-}$ Anion in ATPS PEO/Li $\mathrm{SO}_{4}$

\begin{tabular}{cccc}
\hline$T / \mathrm{K}$ & $\Delta_{\mathrm{tr}} G^{\circ}\left(\mathrm{kJ} \mathrm{mol}^{-1}\right)$ & $\Delta_{\mathrm{tr}} H^{\circ}\left(\mathrm{kJ} \mathrm{mol}{ }^{-1}\right)$ & $T \Delta_{\mathrm{tr}} S^{\circ}\left(\mathrm{kJ} \mathrm{mol}^{-1}\right)$ \\
\hline & & TLL $37 \%(\mathrm{w} / \mathrm{w})$ & \\
278 & -0.561 & 4.19 & 4.75 \\
298 & -0.612 & -4.24 & -3.63 \\
308 & -5.50 & -20.30 & -14.80 \\
318 & -5.44 & -16.90 & -11.46 \\
& & TLL $40 \%(\mathrm{w} / \mathrm{w})$ & \\
278 & -0.640 & -1.39 & -0.75 \\
298 & -0.492 & -5.29 & -4.80 \\
308 & -0.144 & -7.06 & -6.92 \\
318 & -0.009 & -8.71 & -8.70 \\
& & $\mathrm{TLL} 44 \%(\mathrm{w} / \mathrm{w})$ & \\
278 & -0.694 & -8.86 & -8.17 \\
298 & -0.222 & -6.38 & -6.16 \\
308 & 0.035 & -5.26 & -5.30 \\
318 & 0.115 & -0.99 & -1.11 \\
& & $\mathrm{TLL} 48 \%(\mathrm{w} / \mathrm{w})$ & \\
278 & -0.721 & -14.00 & -13.28 \\
298 & 0.004 & -7.07 & -7.07 \\
308 & 0.146 & -3.93 & -4.08 \\
318 & 0.287 & -0.99 & -1.28 \\
& & $\mathrm{TLL} 52 \%(\mathrm{w} / \mathrm{w})$ & -15.57 \\
278 & -0.735 & -16.30 & -8.43 \\
298 & 0.170 & -8.26 & -4.86 \\
308 & 0.218 & -4.64 & 0.78 \\
318 & 0.480 & 1.26 &
\end{tabular}

difference between the two states. ${ }^{31}$ However, when $\Delta_{\mathrm{tr}} H^{\mathrm{o}}{ }_{\mathrm{vH}} \neq$ $\Delta_{\mathrm{tr}} H_{\text {cal }}^{\mathrm{o}}$ it is considered that there is a multistep process occurring between two states with a very small entropy difference. ${ }^{32} \mathrm{On}$ the basis of this approach, we can consider that the $\left[\mathrm{M}(\mathrm{CN})_{5} \mathrm{NO}\right]^{x-}$ anion moves to the top phase, causing innumerous changes (steps) leading to multistates with small entropy differences. These states are probably related to changes in
TABLE 6: Thermodynamic Parameters Obtained with the Nonlinear van't Hoff Equation for $\left[\mathrm{Cr}(\mathrm{CN})_{5} \mathrm{NO}^{3-}\right.$ Anion in ATPS PEO/Na $\mathrm{SO}_{4}$

\begin{tabular}{cccc}
\hline$T / \mathrm{K}$ & $\Delta_{\mathrm{tr}} G^{\circ}\left(\mathrm{kJ} \mathrm{mol}^{-1}\right)$ & $\Delta_{\mathrm{tr}} H^{\circ}\left(\mathrm{kJ} \mathrm{mol}^{-1}\right)$ & $T \Delta_{\mathrm{tr}} S^{\circ}\left(\mathrm{kJ} \mathrm{mol}^{-1}\right)$ \\
\hline & & TLL $30 \%(\mathrm{w} / \mathrm{w})$ & \\
278 & 0.306 & 0.793 & 2.23 \\
298 & 0.558 & -6.53 & -7.09 \\
308 & 0.793 & -10.60 & -11.39 \\
318 & 1.255 & -14.50 & -15.75
\end{tabular}

$\begin{array}{rrrr} & & \text { TLL 33\%(w/w) } \\ 278 & 0.428 & 1.44 & 1.01 \\ 298 & 0.620 & -5.64 & -6.26 \\ 308 & 0.908 & -8.84 & -9.75 \\ 318 & 1.280 & -11.80 & -13.08\end{array}$

$\begin{array}{rrrr}278 & 0.601 & 1.61 & 1.01 \\ 298 & 0.724 & -4.71 & -5.43 \\ 308 & 1.020 & -7.56 & -8.58 \\ 318 & 1.321 & -10.20 & -11.52\end{array}$

\begin{tabular}{lccc} 
& \multicolumn{3}{c}{ TLL 39\%(w/w) } \\
278 & 0.832 & 0.71 & -0.12 \\
298 & 0.933 & -3.68 & -4.61 \\
308 & 1.070 & -5.65 & -6.72 \\
318 & 1.371 & -7.51 & -8.88 \\
& & TLL $42 \%(\mathrm{w} / \mathrm{w})$ & \\
278 & 0.993 & 0.25 & -0.74 \\
298 & 1.166 & -2.75 & -3.92 \\
308 & 1.067 & -4.10 & -5.17 \\
318 & 1.451 & -5.37 & -6.82
\end{tabular}

TABLE 7: Thermodynamic Parameters Obtained with the Nonlinear van't Hoff Equation for $\left[\mathrm{Cr}(\mathrm{CN})_{5} \mathrm{NO}^{3-}\right.$ Anion in ATPS PEO/ZnSO

\begin{tabular}{cccc}
\hline$T / \mathrm{K}$ & $\Delta_{\mathrm{tr}} G^{\circ}\left(\mathrm{kJ} \mathrm{mol}^{-1}\right)$ & $\Delta_{\mathrm{tr}} H^{\circ}\left(\mathrm{kJ} \mathrm{mol}^{-1}\right)$ & $T \Delta_{\mathrm{tr}} S^{\circ}\left(\mathrm{kJ} \mathrm{mol}^{-1}\right)$ \\
\hline & & $\mathrm{TLL} 37 \%(\mathrm{w} / \mathrm{w})$ & \\
278 & -4.178 & -13.30 & -9.12 \\
298 & -3.616 & -12.90 & -9.28 \\
308 & -3.130 & -12.80 & -9.67 \\
318 & -2.967 & -12.70 & -9.73 \\
& & $\mathrm{TLL} 40 \%(\mathrm{w} / \mathrm{w})$ & \\
278 & -5.235 & -17.60 & -12.37 \\
298 & -5.082 & -21.60 & -16.52 \\
308 & -3.704 & -30.50 & -26.80 \\
318 & -3.272 & -38.90 & -35.63 \\
& & $\mathrm{TLL} 43 \%(\mathrm{w} / \mathrm{w})$ & \\
278 & -6.895 & -19.50 & -12.61 \\
298 & -5.837 & -31.20 & -25.36 \\
308 & -4.309 & -36.50 & -32.19 \\
318 & -3.683 & -41.40 & -37.72 \\
& & $\mathrm{TLL} 46 \%(\mathrm{w} / \mathrm{w})$ & \\
278 & -8.313 & -39.70 & -31.39 \\
298 & -6.279 & -37.80 & -31.52 \\
308 & -4.898 & -36.90 & -32.00 \\
318 & -4.161 & -36.10 & -31.94 \\
& & $\mathrm{TLL} 49 \%(\mathrm{w} / \mathrm{w})$ & -48.95 \\
278 & -9.452 & -58.40 & -35.26 \\
298 & -6.538 & -41.80 & -28.83 \\
308 & -5.466 & -34.30 & -22.54 \\
318 & -4.658 & -27.20 &
\end{tabular}

polymer conformations, molecular dehydration, water transfer between the phases, and aggregates formation.

\section{Conclusion}

Partitioning behaviors of pentacyanonitrosylmetallate anions, $\left[\mathrm{M}(\mathrm{CN})_{5} \mathrm{NO}\right]^{x-}(\mathrm{M}=\mathrm{Fe}, \mathrm{Mn}$, or $\mathrm{Cr})$, in $\mathrm{PEO} / \mathrm{M}_{x} \mathrm{SO}_{4} / \mathrm{H}_{2} \mathrm{O}$ ATPS 


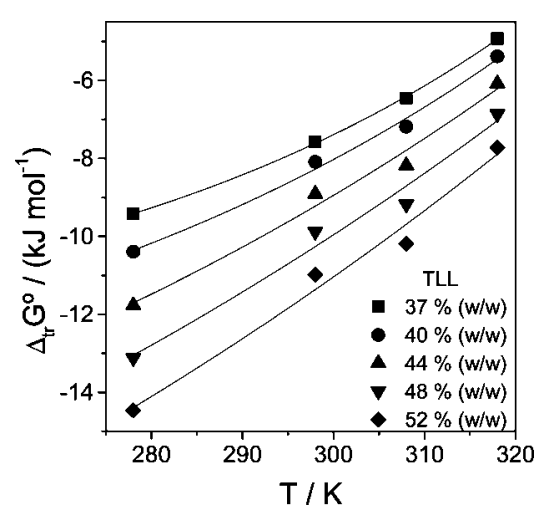

Figure 11. $\Delta_{\mathrm{tr}} G^{\mathrm{o}}$ vs temperature for the complex $\left[\mathrm{Mn}(\mathrm{CN})_{5} \mathrm{NO}\right]^{3-}$ in the $\mathrm{PEO} / \mathrm{Li}_{2} \mathrm{SO}_{4} / \mathrm{H}_{2} \mathrm{O}$ ATPS.

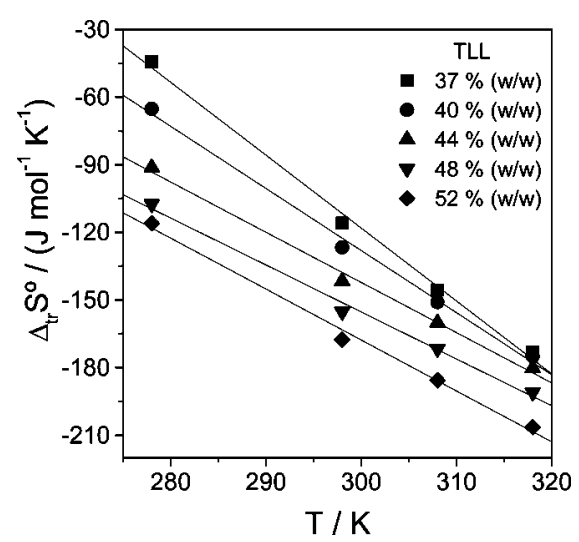

Figure 12. $\Delta_{\mathrm{tr}} S^{\mathrm{o}}$ vs temperature for the complex $\left[\mathrm{Mn}(\mathrm{CN})_{5} \mathrm{NO}\right]^{3-}$ in the $\mathrm{PEO} / \mathrm{Li}_{2} \mathrm{SO}_{4} / \mathrm{H}_{2} \mathrm{O}$ ATPS.

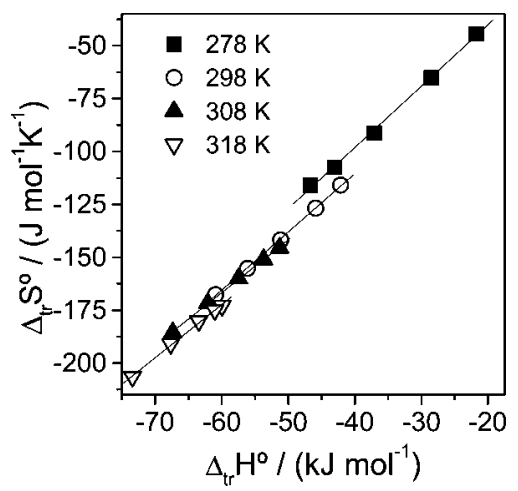

Figure 13. Plots of $\Delta_{\mathrm{tr}} H^{\circ}$ versus $\Delta_{\mathrm{tr}} S^{\circ}$ for the complex $\left[\mathrm{Mn}(\mathrm{CN})_{5} \mathrm{NO}\right]^{3-}$ in four different temperatures in ATPS formed with $\mathrm{PEO} / \mathrm{Li}_{2} \mathrm{SO}_{4} / \mathrm{H}_{2} \mathrm{O}$.

are strongly influenced by the nature of the central atom. For all ATPS and temperatures examined, the partitioning coefficient follows the order $K_{\left[\mathrm{Fe}(\mathrm{CN})_{5} \mathrm{NO}\right]^{2-}} \gg K_{\left[\mathrm{Mn}(\mathrm{CN})_{5} \mathrm{NO}\right]^{3-}}>K_{\left[\mathrm{Cr}(\mathrm{CN})_{5} \mathrm{NO}\right]^{3-}}$. This sequence in $K$ values was attributed to the effect of the central atom in the specific $\mathrm{EO}-\left[\mathrm{M}(\mathrm{CN})_{5} \mathrm{NO}\right]^{x-}$ enthalpic interaction. On the basis of this model and as a result of the replacement of the iron central atom with manganese or chromium, there is an increase in the $\mathrm{NO}^{+}$electronic density, mainly due to formation of $\pi$ bonds, thus decreasing the tendency of the complex to interact with electronic pairs found in the oxygen atoms of the ethylene oxide. Furthermore, another effect in the partitioning behavior has been verified for the ATPS-forming salt, resulting for all complexes the order $K_{\mathrm{Li}_{2} \mathrm{SO}_{4}}^{\left[\mathrm{M}(\mathrm{CNO})^{2} \mathrm{NO}^{\mathrm{x}}\right.} \gg K_{\mathrm{Na}_{2} \mathrm{SO}_{4}}^{\left[\mathrm{M}(\mathrm{CN})_{5} \mathrm{NO}^{\mathrm{x}}\right.}>K_{\mathrm{ZnSO}_{4}}^{\left[\mathrm{M}(\mathrm{CN})_{5} \mathrm{NO}^{\mathrm{x}}\right]^{-}}$. The electrolyte effect was attributed to an interaction between the ATPS-forming salt cation and the PEO macromolecules,

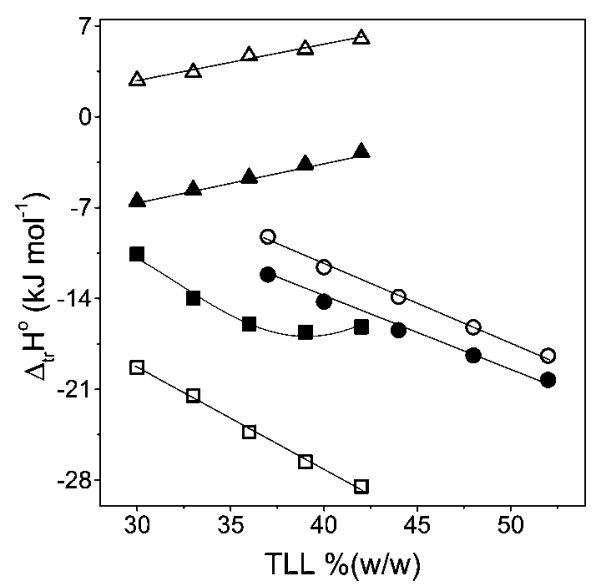

Figure 14. Calorimetric (full symbol) and van't Hoff (open symbol) $\left[\mathrm{Fe}(\mathrm{CN})_{5} \mathrm{NO}\right]^{2-}(\mathbf{\square}, \square),\left[\mathrm{Mn}(\mathrm{CN})_{5} \mathrm{NO}\right]^{3-}(\bullet, \mathrm{O})$, and $\left[\mathrm{Cr}(\mathrm{CN})_{5} \mathrm{NO}\right]^{3-}$ $(\pi, \rho)$ enthalpy of transfer obtained in the PEO/Na $\mathrm{SO}_{4} / \mathrm{H}_{2} \mathrm{O}$ ATPS systems at $25{ }^{\circ} \mathrm{C}$.

generating a positively charged polymer surface, which can interact with the $\left[\mathrm{M}(\mathrm{CN})_{5} \mathrm{NO}\right]^{x-}$ anion. According to this idea the cation plays a role by interacting simultaneously with complex anions and PEO. All these important results suggest the use of pentacyanonitrosylmetallate anion as a strategic additive, aiming to change physical chemistry properties of systems formed with mixtures of poly(ethylene oxide) and electrolytes.

Acknowledgment. We gratefully acknowledge Fundação de Amparo à Pesquisa do Estado de Minas Gerais (FAPEMIG) for financial support of this project. K.R.F. and M.V.C.C. thank Conselho Nacional de Desenvolvimento Científico e Tecnológico $(\mathrm{CNPq})$ for scholarships.

\section{References and Notes}

(1) Yan, Y.; Besseling, N. A. M.; de Keizer, A.; Stuart, M. A. C. J. Phys. Chem. B 2007, 111, 5811-5818.

(2) Zhang, L.; Yao, Y. Z.; Ye, X. F.; Wu, Q. J. Phys. Chem. B 2007, $111,335-339$.

(3) Vaucher, S.; Fielden, J.; Li, M.; Dujardin, E.; Mann, S. Nano Lett. 2002, 2, 225-229.

(4) Rakhimov, R. R.; Hwang, J. S.; Prokof'ev, A. I.; Alexandrov, I. A.; Zelenetskii, A. N.; Aleksandrov, A. I. J. Appl. Phys. 2004, 95, 7342-7344.

(5) Holmes, S. M.; Girolami, G. S. Mol. Cryst. Liq. Cryst. A 1997, 305, 279-290.

(6) Thakur, A. K.; Pradhan, D. K.; Samantaray, B. K.; Choudhary, R. N. P. J. Power Sources 2006, 159, 272-276.

(7) Borodin, O.; Smith, G. D.; Douglas, R. J. Phys. Chem. B 2003, 107, 6824-6837.

(8) Ericson, H.; Mattsson, B.; Torell, L. M.; Rinne, H.; Sundholm, F. Electrochim. Acta 1998, 43, 1401-1405.

(9) Sartori, R.; Sepulveda, L.; Quina, F.; Lissi, E.; Abuin, E. Macromolecules 1990, 23, 3878-3881.

(10) Graber, T. A.; Medina, H.; Galleguillos, H. R.; Taboada, M. E. J. Chem. Eng. Data 2007, 52, 1262-1267.

(11) da Silva, L. H. M.; da Silva, M. D. H.; Mesquita, A. F.; do Nascimento, K. S.; Coimbra, J. S. R.; Minim, L. A. J. Chem. Eng. Data 2005, 50, 1457-1461.

(12) Fernandes, S.; Kim, H. S.; Hatti-Kaul, R. Protein Expres. Purif. 2002, 24, 460-469.

(13) Hespanhol da Silva, M. C.; Mendes da Silva, L. H.; Paggioli, F. J.; Reis Coimbra, J. S.; Minim, L. A. Quim. Nova 2006, 29, 1332-1339.

(14) Rogers, R. D.; Bauer, C. B.; Bond, A. H. Sep. Sci. Technol. 1995, $30,1203-1217$.

(15) da Silva, L. H. M.; da Silva, M. C. H.; de Aquino, R. A. N.; Francisco, K. R.; Cardoso, M. V. C.; Minim, L. A.; Coimbra, J. S. R. J. Phys. Chem. B 2006, 110, 23540-23546.

(16) Griffith, W. P.; Lewis, J.; Wilkinson, G. J. Chem. Soc 1959, 17751779

(17) Cotton, F. A.; Monchamp, R. R.; Henry, R. J. M.; Young, R. C. J. Inorg. Nucl. Chem. 1959, 10, 28-38. 
(18) Carvalho, C. P.; Coimbra, J. S. R.; Costa, I. A. F.; Minim, L. A. Silva, L. H. M.; Maffia, M. C. J. Chem. Eng. Data 2007, 52, 351-356. (19) Martins, J. P.; Carvalho, C. P.; da Silva, L. H. M.; Coimbra, J. S. R.; da Silva, M. D. H.; Rodrigues, G. D.; Minim, L. A. J. Chem. Eng. Data 2008, 53, 238-241.

(20) Ruiz-Angel, M. J.; Pino, V.; Carda-Broch, S.; Berthod, A. J. Chromatogr. A 2007, 1151, 65-73.

(21) da Silva, L. H. M.; Loh, W. J. Phys. Chem. B 2000, 104, 1006910073.

(22) Tada, E. D.; Loh, W.; Pessoa, P. D. Fluid Phase Equilib. 2004, 218, 221-228.

(23) da Silva, L. H. M.; da Silva, M. C. H.; Amim Junior, J.; Martins, J. P.; Coimbra, J. S. R.; Minim, L. A. Sep. Purif. Technol. 2008, 60, 103112

(24) Molochnikov, L. S.; Kovalyova, E. G.; Zagorodni, A. A.; Muhammed, M.; Sultanov, Y. M.; Efendiev, A. A. Polymer 2003, 44, 48054815 .
(25) Perumalsamy, M.; Murugesan, T. Fluid Phase Equilib. 2006, 244 , $52-61$.

(26) Haraguchi, L. H.; Mohamed, R. S.; Loh, W.; Pessoa, P. A. Fluid Phase Equilib. 2004, 215, 1-15.

(27) Johansson, H. O.; Karlström, G.; Tjerneld, F.; Haynes, C. H. J. Chromatogr. B 1998, 711, 3-17.

(28) Gomez, J. A.; Guenzburger, D. Chem. Phys. 2000, 253, 73-89.

(29) Hollauer, E.; Olabe, J. A. J. Brazilian Chem. Soc. 1997, 8, 495504.

(30) Oszajca, J.; Stochel, G.; Wasielewska, E.; Stasicka, Z.; Gryglewski, R. J.; Jakubowski, A.; Cieslik, K. J. Inorg. Biochem. 1998, 69, 121-127. (31) Bakk, A.; Metzler, R. Chem. Phys. Lett. 2004, 398, 190-193.

(32) Boysen, R. I.; Wang, Y.; Keah, H. H.; Hearn, M. T. W. Biophys. Chem. 1999, 77, 79-97.

JP711617Z 